\title{
眼球突出を主訴とした原発性肝癌の一剖検例
}

\author{
田中 耕一・大迫 茂人*・黒木 哲夫** \\ 箕輪 孝美・嶋崎 昌義***
}

\section{Autopsy Report on Primary Hepatic Cancer of a Patient who Complained of Exophthalmos}

\author{
Koichi Tanaka, Shigeto Osako, Tetsuo Kuroki, \\ Takayoshi Minowa and Masayoshi Shimazaki \\ (Internal Medicine Section 3, Osaka City Univ.) (Pathology Section 2, Osaka City Univ.) \\ (Osaka Gity Univ.)
}

Unilateral exophthalmos is frequently complained of in the field of otorhinology, but the ethiological diagnosis is occasionally difficult. The patient herein reported visited our hospital complaining of exophthalmos and visual disturbance of the left eye. After a variety of examinations, a metastatic lesion originating from hepatic cancer was detected in the ophthalmic region. It was additionally demonstrated that a tumor growing near the left 6 th-rib was also the result of metastasis from the hepatic cancer.

\section{I 緒言}

一側性眼球突出を主訴とする疾患は耳鼻科領域においては稀な疾患ではないが，時としてその病 因確定が困難なととがある。今回著者らは一側性眼球突出を初発症状としたため, その診断が非常 に困難であった肝細胞癌の眼窩周囲への転移症例を経験したので，乙の極めて稀な症例の临床所見 ならびに剖検所見について，若干の考察をまじえて報告する。

II 症例

症例 : 49才 男性

初唁: 昭和 50 年 1 月 9 日

主訴 : 左眼球突出, 左視力低下

既往歴：44才 慢性肝炎の疑い。

現病歴：昭和 49 年 1 月頃より，左鼻閉感が軽 度存在したが放置していた。
49年10月頃より，上記の症状が増強し，近医耳 鼻咽喉科受診, 約 1 力月間治療を受けたが, 症 状は軽快せず，同年12月頃より，左上眼瞼腫 張, 左視力低下を認め, 近医眼科受診, 治療を 受けたが，徐々に眼球突出が増強し，且眼瞼下 垂が出現し，当院眼科へ紹介され，更に眼科よ

\footnotetext{
$*$ 大阪市立大学医学部耳鼻咽喉科学教室

**大阪市立大学医学部第三内科学教室

****阪市立大学医学部第二病理学教室
} 


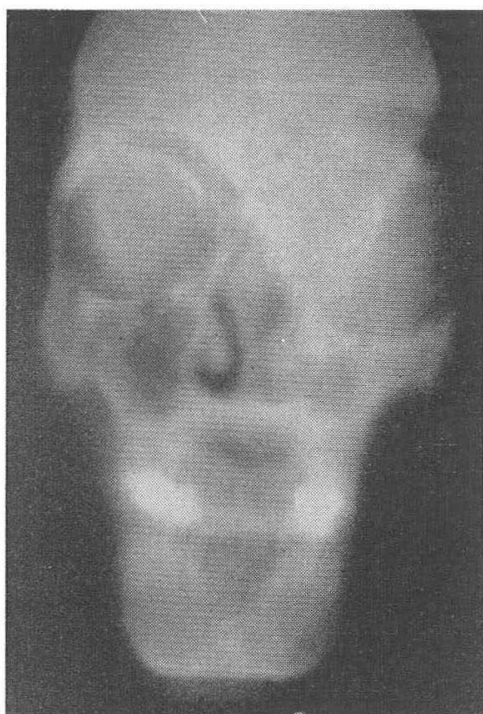

図 1 副鼻控断層撮影

り昭和 50 年 1 月 9 日当科を紹介された。 初診時所見：両鼓膜正常。左中鼻道上り漿液 鼻漏が中等量認められ，副鼻腔レ線像では図 1 のごとく左上顎洞および節骨洞，前頭洞に異常 除影を認めた。そこで精查の目的で昭和 50 年 1 月31日入院した。

入院後の経過 : 入院時, 左眼球突出と同時期 から出現したと思われる腫瘍を左胸壁飞認め た。胸部レ線上では図 2 のごとく陰影欠損像を 認めた。

入院後，2 月 4 日まず左上顎洞試験開放術を 施行。上顎洞の粘膜は浮腫状である以外，腫陽 の所見はなく，また穊骨洞にむ腫瘍らしい所見 は存在しなかった。哏窩下壁の骨欠損屯認めら

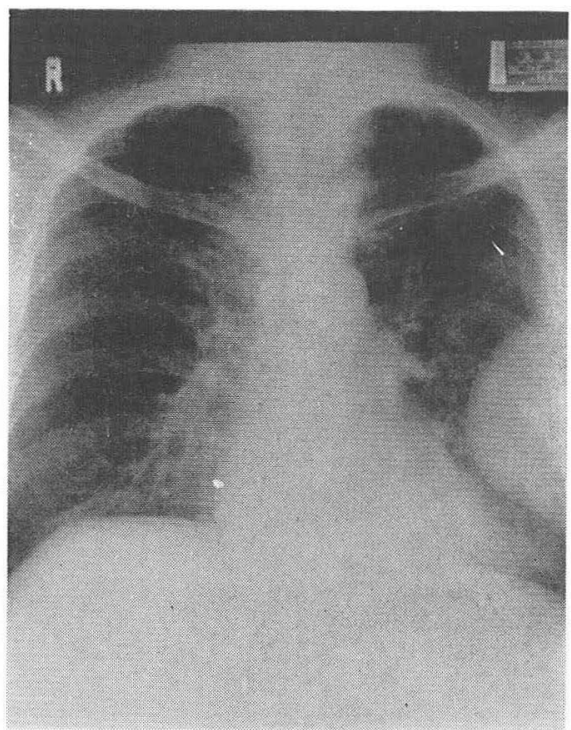

図 2 胛部レ線

れなかった。さらに2月19日左胸壁媑瘍より組 織診を行なったが，確診できず，3 月 6 日全麻 下左前頭洞開放術施行。前頭洞前壁の骨欠損は なかったが，骨は㧪弱で易出血性の腫瘍が前頭 洞に充満しており，出血量約 $2,000 \mathrm{cc}$ に及び 腫瘍の全貌を知るととなく，途中で手術を中止 した。この際の組織診は「骨肉腫の疑い」であ つた。

一方左上顎洞試験閒放術後麻酔からの覚醒が 覀く，一般肝機能検查上表 1 のごとく alk $-\mathrm{P}$, LAP の中等度上昇索認めるため，3月25日 ${ }^{99 \mathrm{~m}} \mathrm{~T}_{\mathrm{C}_{2}} \mathrm{~S}_{7}$ コロイドによる师シンチグラフィー を施行した。朋シンチグラム正面像（図 3 ）, 右側面像（図 4 ）によって肝右葉上外側に Cold
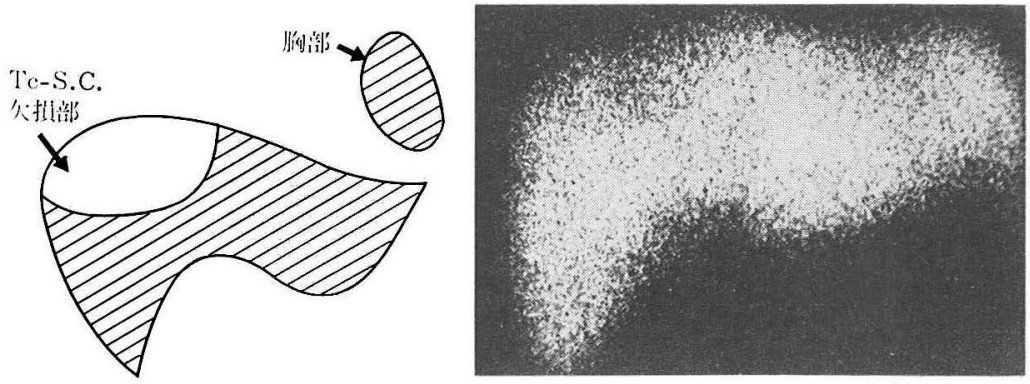

図 3 肝シンチ 一正面像一 

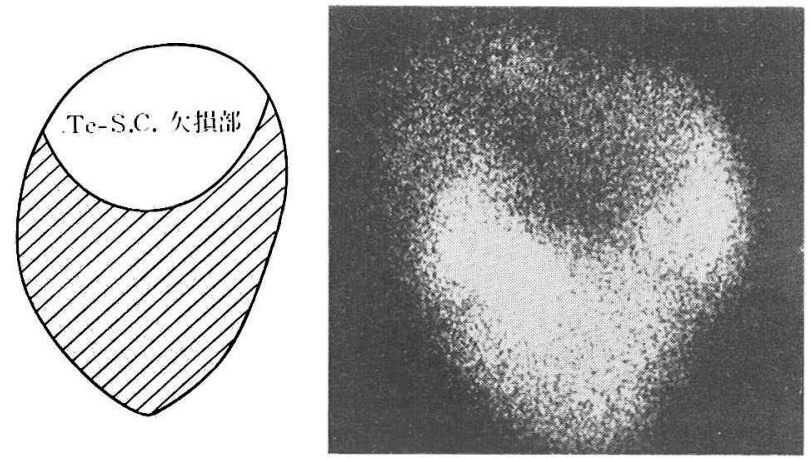

図 4 肝シンチ 一右側面像一

表 1 経 過

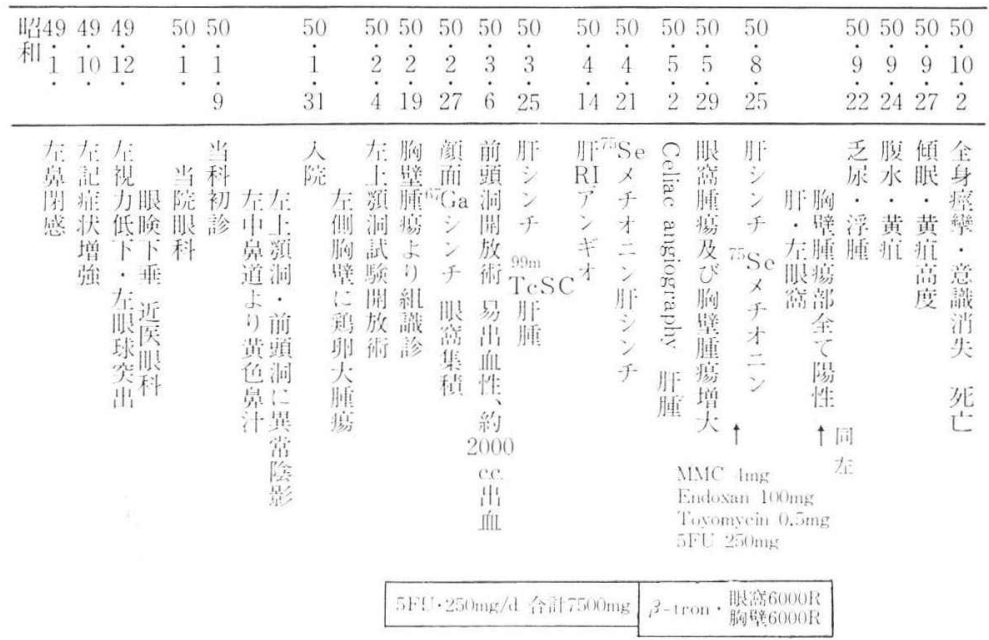

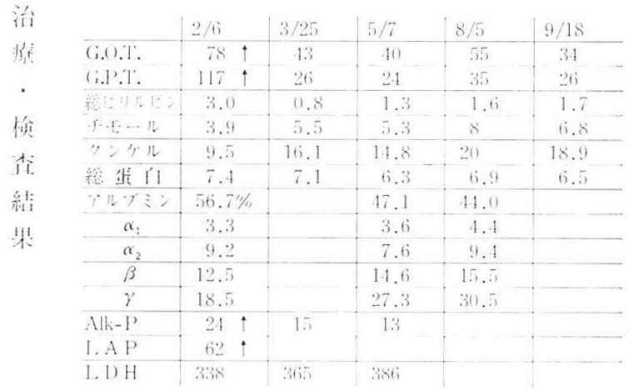

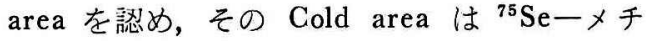
オニンによる腫瘍シンチグラムでは陽性描画を 示し，原発性肝癌の合併が疑診された。その間 $5 \mathrm{Fu}$ を全身投与したが, 眼窩部, 左胸壁腫湯 は次第に増大を示すために，5月 6 日より左眼

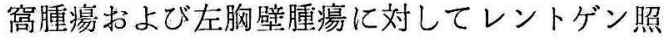
射を開始。また朋動脈撮影洔に MMC $20 \mathrm{mg}$ 動注, 全身的には $\mathrm{MMC} 4 \mathrm{mg}$, Endoxan $10_{0}$ $\mathrm{mg}$, Toyomycin $0.5 \mathrm{mg}, 5 \mathrm{Fu} 250 \mathrm{mg}$ 等を投 与したが，それにもかかわらず，三ケ所の腫瘍 
は次第に增大を示した。8月25日左眼窩部，左 胸壁, 肝癌の 3 ケ所の腫痬について ${ }^{75} \mathrm{Se}-x チ$ オニンによる腫痬シンチグラムを施行したとと

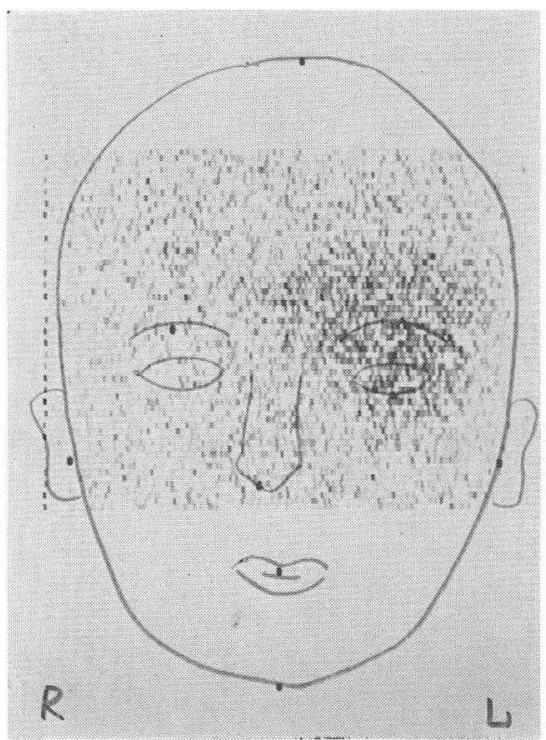

図 $5 \quad{ }^{75} \mathrm{Se}$ 一メチオニンの眼窩周团への取り込み

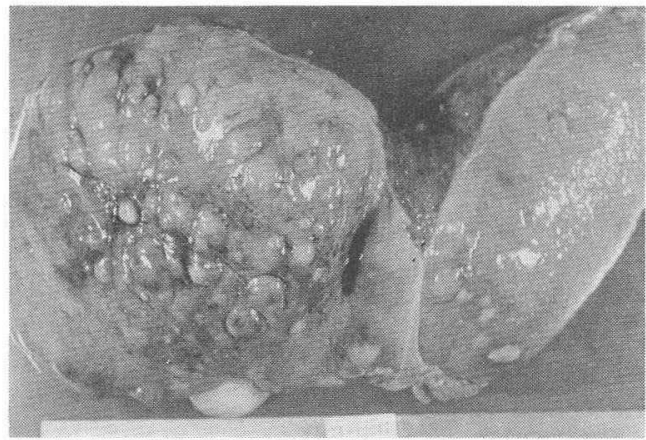

図 6 剖検時摘出肝

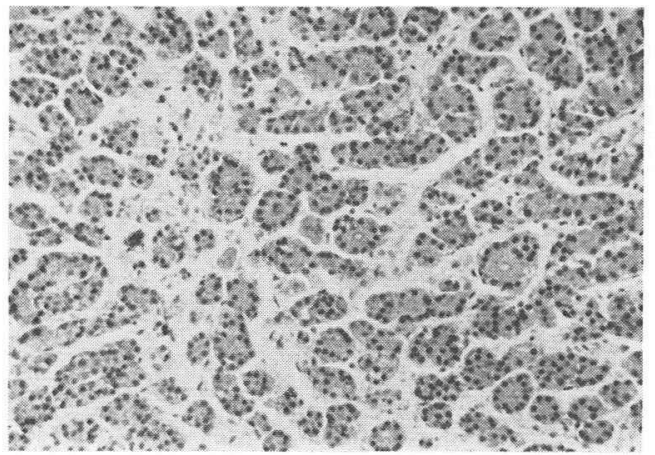

図 7 摘出肝組織像
ろ，肝腫痬以外に左胸壁腫瘍，および左眼窩部 腫瘍（図 5) にすべて ${ }^{75} \mathrm{Se}$-メチオニンの強い 集積を浔め, 原発性肝稆の左:哏窩周团, 左胸壁部 (第 6 助骨) への転移が強く疑われた。その後 屯腫瘍は治療に全く反忘せず，徐々に増大し， 黄㾝, 腹水が出现し，10月 2 日鬼籍に入った。 本症例の全経過は表 1 のごとくである。

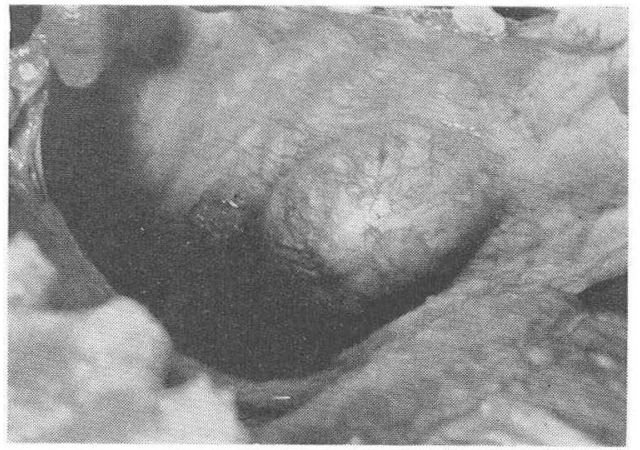

図 8 左胸壁腫瘍

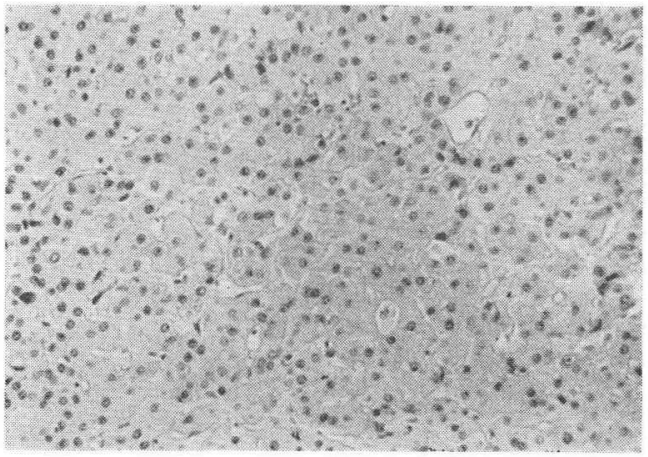

図 9 胸壁腫瘍 組織像

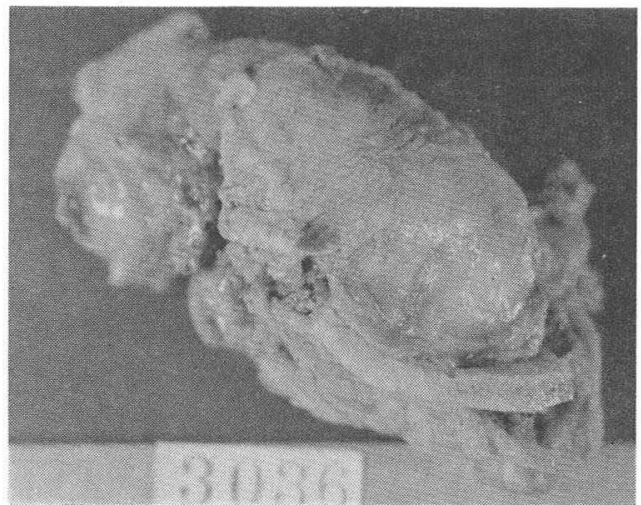

図10 前頭洞から眼窩にかけての腫瘍 


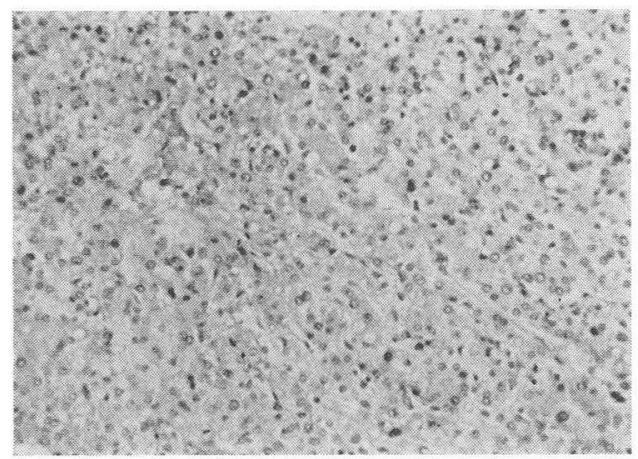

図11 前頭洞から腿窩にかけての腫瘍の組織像

剖検所見：肞には肉眼的に多発性腫瘤が認め られ (図6) 組織学的には成熟型肝細胞癌であ った。(図 7) そして一部には腺管形成を示す ところがあり腺腔内に胆汁の存在の認められる 部むみられた。また左胸壁腫瘤は第 6 胁学に続 く周囲との境界明瞭な腫瘤（図 8 ) でその組織 像は本質的には肝の腫瘍之同様で索状配列の傾 向をもったやや異型性のある細胞の増殖より成 っており（図 9) 肝癌の転移巣と考えられた。

\section{III 考}

一側眼球突出を来たす疾患には種々記載され ているが，山田等"1はこれらを大きく副鼻腔疾 患, 眼窩の炎症性疾患, 哏窩腫瘍, 血管性疾患, 内分泌疾患と分類し, 眼窩腫瘍として骾膜腫, 横 紋筋肉腫，転移性癌を挙げ，転移性癌について は, その原発癌に乳癌, 子宮癌, 前立腺癌, 甲 状腺癌，上顎癌等を举げている。また石原等 ${ }^{2)}$ はその他に頭蓋奇形による眼球灾出む述べてい る。Forrest ${ }^{3)}$ は眼窩に認められる38例の二次性 腫陽の内訳として, 組織学的に癌腫24例, 神経 芽細胞腫 6 例，忢性黑色腫 6 例，網膜膠質腫 1 例, 下垂体腺腫 1 例があったとしており，癌腫 24例のうち, 眼球突出を主訴としたあのが 6 例 で, 胸部の腫痬が 3 例, 副鼻腔腫瘍が 2 例, 結 膜腫瘍が 1 例であったとしている。しかし肝癌 が原発宩であった例は記載されていない。一方 肝癌の朋外転移の頻度については, El-Domeiri et $\mathrm{al}^{4)}$. による30\%から Patton et al. ${ }^{5)}$ による
さらに眼窩周辺の骨抢よび眼窩内，前頭洞にも 腫瘍の浸潤を認め(図10), 組織学的にも肝の 腫瘍と略一致する像を示した。(図11) 剖検所 見の概要は表 2 に一括した。

表 2 病理解剖診断

\begin{tabular}{|c|c|}
\hline $\mathrm{I}$ & $\begin{aligned} \text { 肝細胞癌（結節型, 成熟型) } \\
\text { 転移 : } \\
\text { 閘脈内塞栓（膵内血管に及ぶ） } \\
\text { 第 } 6 \text { 肋骨 } \\
\text { 左眼窩周辺の骨及び眼窩内, } \\
\text { 前頭洞, 副腎, 等 }\end{aligned}$ \\
\hline II & 腹水1700 c. c. \\
\hline III & 肺水腫と肺内出血（右上葉, 両下葉） \\
\hline IV & 胆血症性腎症, 左上部尿管の重複 \\
\hline $\mathrm{V}$ & $\begin{array}{l}\text { 左前頭葉, クモ膜にへモジデリン沈着と, クモ } \\
\text { 膜下腔に暍液の蓄溜, 類港粉小体形成 }\end{array}$ \\
\hline $\mathrm{VI}$ & 副腎内出血 \\
\hline VII & 上皮小体の軽度過形成 \\
\hline VIII & 脾のうっ血, 形質細胞増生 \\
\hline IX & 睪丸の萎縮 \\
\hline $\mathrm{X}$ & $\begin{array}{l}\text { 全身黄疽 } \\
\text { その他 }\end{array}$ \\
\hline
\end{tabular}

按

80\%にいたる非常に巾広い值が報告されてい る。しかし一般には飯野等 ${ }^{6)}$, 藤本等 ${ }^{7)}$ の報告に 胃られるごとくその頻度は70～80\%とされ，そ の転移部位としては肺およびリンパ節に多い上 されている。しかし肝癌の骨転移については, その頻度は El-Domeiri et al, $\%$, Patton et al.5) によれば20\%位, Byrne et al. ${ }^{8)}$ によれば 3 12\%であるとされている。従 って骨転移の頻度はその他の部位への転移頻度 に比較して少ない。骨転移についての報告は, 1973年 Bolker et al. ${ }^{97}$ がそれまでの症例 9 例之 自験例 1 例とを合せてその部位について検討し た結果，転移部位としては鎖骨，椎体骨，大腿 骨，仙骨，胸省等が報告されている。また上記 の骨の病的骨折を初発症状とした Talerman et al. ${ }^{10)}$ や飯野等 ${ }^{6)}$ の報告もある。その後の報告 あ，上記の骨への転移が殆んどである。珍らし い例として, Dick et al ${ }^{11)}$ は口唇部の腫張を初 
発症状とし，下顎骨に転移した症例を報告して おり，さらに Reichback et al. ${ }^{12)}$ は珍らしい症 例 2 例を報告しているが， 1 例は左側の難聴を 伴い，観骨弓の腫張を初発症状とした症例であ り，さらに 1 例は手の親指の腫張と疼痛を初発 症状とした症例である。

本症例のような一側眼球突出および視力障害 を主訴とし，レントゲン検査の結果，あたかむ 副鼻腔腫瘍の像を示した症例は著者等の知る限
りでは今迄にその報告は見られていない。

このように本症例は極めて稀な肝癌の眼, 耳 鼻科領域への転移症例の耳鼻科への受晾症例で あったため，その診断に非常に困難をきたした が， ${ }^{75} \mathrm{Se}$-メチオニンによる腫痬シンチスキャン ニング，特に肝癌転移病巣に拈ける腫瘍シンチ グラフィー ${ }^{13)}$ がその腫痬の本態の診断に有効で あった点，示唆するととろの多い症例と考えら れる。

\section{語}

我々は左側眼球突出および視力障害を主訴として受診, 種々検索の結果，肝癌の転移巣であり， 同時に左第 6 肋骨周辺の腫瘍 屯肝癌の転移巣であった極めて稀な症例を経験したので 報告した。

本論文の要旨は, 第15回日本鼻副鼻腔学会（於広島市，1976，10），第 180 回日本耳鼻咽喉科学会大阪地方会 (於大阪市，1977，2 ），第11回日本肝臟学会西部会（於久留米市，1976，10）に於いて口演した。

稿を終るにあたり，御指導御校閲頂きました恩師中井義明教授に感謝の意を表します。

猶この小論文を薬石効なく死去された，M. A 氏の御霊前にささげると共に，我々の剖検の申し出に，気持ち 良く応じていただいた御遺族の方に厚く御礼申し上げます。

文

1）山田修, 他: 一側性眼球突出の診断 耳喉 : 265 271, 1975.

2) 石原 忍, 萩原 朗 : 小眼科学 金原出版 312 〜316, 1963.

3) Forest, A.W.: Intra-orbital tumors. Arch. Ophthal. 41: 198-232, 1949.

4) El-Domeiri, A.A. et al.: Primary malignant tumors of the liver. Cancer 27: 7-11, 1971.

5) Patton, R.B. and Horn, Jr., R.G.: Primary liver carcinoma. Cancer 17: 757-768, 1964.

6）飯野四郎，他：骨転移を初発症状とした肝癌の 一例. 肝臟 $16: 725,1975$.

7) 藤本高義, 他 : 術後 8 年目に腹壁再発を来した 原発性肝癌の一例.

肝臟 $16: 724,1975$.

8) Byrne, M.J. et al.: Hepatocellular carcinoma: presentation with vertebral metastases and radicular compression. Cancer 30: 202-205, 1972.

9) Bolker, H. et al.: Primary carcinoma of the liver with bone metastasis. Ann. Intern.
献

Med. 10: 1212-1221, 1937.

10) Talerman, A. and Magyar, E.: Hepatocellular carcinoma presenting with pathologic fracture due to bone metastasis. Cancer 32: 1477-1481, 1973.

11) Dick, A. et al.: Primary Hepatoma with Metastasis to the Mandible. Am. J. Surg., 94: 846-850, 1957.

12) Reichbach, E.J. et al.: Unusual Osseous Metastases of Hepatoma. J.A.M.A. 213: 2078-2079, 1970.

13) Eddleston, A.L.W.F., et al.: ${ }^{75}$ Se-selenomethionine in the scintiscan diagnosis of primary hepatocellular carcinoma. Gut. 12: 245-249, 1971.

$\left(\begin{array}{l}\text { 原稿到着 : 昭和 } 52 \text { 年 } 10 \text { 月 } 22 \text { 日 } \\ \text { 別刷請求先 : 田中耕一 } \\ \text { 丞 } 545 \text { 大阪市阿倍野区旭町 } 1-5-7 \\ \text { 大阪市立大学医学部耳鼻咽喉科学教室 }\end{array}\right)$ 